\title{
BANKINg Services And Distribution Channels - Evolution ANd Prospects
}

\author{
Łukasz Murowaniecki \\ Department of Computer Science in Economics \\ University of Lodz, Łódź, Poland \\ lukaszm@uni.lodz.pl
}

\begin{abstract}
The article presents the process of evolution of banking services and banking distribution channels. It deals with the history and identifies main factors that affecting the change. In the following discussion, it presents phenomena that affect the future appearance of banking. These include changes in the economic and technological environment.
\end{abstract}

Key words: Banking service, distribution channel, IT in banking.

\section{Introduction}

Banking is an area of dynamic changes caused by many factors. Because of the role that banks play in the economy and, more broadly, in our lives, it is worthwhile to look at this phenomenon. Those changes apply to business model, the range of activities and also technological solutions.

Below, it is presented the author look at the process of evolution of banking services and bank distribution channels. In addition, the current trends and prospects in this area are indicated.

Such consideration has been provoked by many interesting and revolutionary statements presented in banking environment. To mention one example, the CEO of mBank, one of the biggest and most innovative bank in Poland, said that the bank branch, cash and signature - the pillars of traditional banking - at an accelerated pace no longer correspond to the rhythm of our day [1]. 


\section{Bank products and services in distribution channels}

We cannot find in the bibliography a clear and settled set of terms to describe the subject of the banking business. Such terms as 'operation', 'product' and 'services' are used interchangeably in banking context.

The Polish Banking Law defines the concept of banking operations [2]. There are distinguished: accepting cash deposits, lending, payment services. The concept of banking (financial) services appears in EU directives. A service is any activity, which the bank performs for the customer (e.g. current account management, granting a loan, money transfer, credit card payment execution). On the other hand, in the practitioners language, the bank offers products, which is consistent with the nomenclature of marketing.

From the information systems analyst point of view, I have adopted the following interpretation of terms. The bank sells products to customers, as a part of its activities. Products can be both material objects (e.g. a safety box) or immaterial (e.g. current account, credit card). As a part of product maintenance, the bank provides services to the client. The availability of services and rules for their implementation are described in the regulations of the product.

We can distinguish the following groups of banking services:

- deposit,

- credit,

- settlement,

- foreign transactions handling,

- investment,

- capital,

- information and consulting,

- other (e.g. Storage items).

Another important term for further analysis is a distribution channel (or 'delivery channel'). It can be defined as a medium by which a financial institution provides services to customers. [3]

There are following distribution channels:

- sale in the bank branch,

- direct sales,

- indirect distribution (via email, dealers, franchise, etc.)

- remote channels; in this group we can distinguish:

- phone channels (phone service, teleservice, hotline)

- home banking

- self-service devices (ATMs, Infomats, bank kiosks, etc.)

- Internet channel,

- mobile channels.

It should be remembered that various banking services can be done through various distribution channels. Typically, a service is not closely linked to one channel. In banking practice, we can observe the presence of 
a matrix relationship between services and distribution channels. It is a time varying matrix. Firstly, because both the list of banking products and services as well as the list of distribution channels expand. In addition, the availability of a particular service in a particular channel also changes. Typically, banks try to expand this availability.

\section{The evolution of distribution channels}

From the customer point of view, the evolution of distribution channels is the most influencing factor on the perception of banking activities. Modern distribution channels demonstrate the bank competitiveness. It is something what can be used as a bank trademark.

As an example could be an investment of mBank between years 2012 and 2013 into refreshing and extension their Internet and mobile distribution channels. It was valued at over 100 million PLN $[4,5]$. This investment allowed the bank to provide their customers a radically altered Internet Banking channel and a new mobile application. This change, further strengthened by several international prizes [6] for its innovative interface and functionality of the banking system, has become a very powerful tool for promotion of the whole bank.

Another example is the strategy of Alior Bank. In 2012 it entered the market by promoting itself as the only fully online bank in Poland, investing in the project the amount of 50 million PLN [7]. A characteristic feature of the bank was supposed to be an Internet channel enabling access for the realization of all services.

Looking historically it must be admitted that channels of selling banking products have come a long way. Originally, a distribution of products and services was closely linked to a bank's headquarters location, a distance from the customer, banking hours. Products selling required a direct contact of a bank employee with the client. In order to maintain this way of operating, banks have heavily expanded its distribution network, which included bank branches and other non-bank service points. The need to reduce the physical distance between the institution and the customer has become the basis for the development of cooperative banks and other type of shadow banks and credit unions.

The first revolution in access to banking services took place with the development of telecommunication networks. This allowed the implementation of self-service distribution channels. The first was a telephone channel. First, only for information services, and then also for simple operations (e.g. a transfer order to the defined recipient). Subsequently, a call center was introduced for marketing purposes, handling complaints and more complex operations (e.g. card restriction, requests for products). 
Another revolution brought the development of electronics, including computer technology. Electronic distribution channels has been developed. The whole implementation of banking services in these channels is called as electronic banking or just e-banking.

The evolution of electronic banking took place in several directions, simultaneously with the development of new electronic devices and technologies. The most important are:

- ATM - a stationary device the size of a man. Initially it took the form of information terminal, then the functionality has grown. Currently, we have to do with such devices as Cash Dispenser, ATM, cash deposit machine, cashless ATMs.

- Television - a device present in almost every households. Use it to realize banking services is referred to as banking television. At first, because of a one-way communication channel was limited for information role. Nowadays, TV can perform similar functions like a computer.

- POS - together with the use of plastic bank cards, and more recently mobile phones, is widely used in the retail sector as a channel for clearing services.

- Personal computer - a multi-functional device. It is used in several different ways. Initially it was a tool to run applications such as home banking, allowing to register financial operation off-line (later also on-line) and then interchange them with the bank by phone line or Internet. Currently, dominated by use of a computer as a tool to access bank websites.

- Mobile phones - can be used as an access device for several distribution channels (telephone, Internet, mobile). Its form and functionality begins to overlap with the PC. An important difference is that the mobile phone includes a personalized SIM card that gives additional possibilities, for example it can be used for user authentication.

In the context of electronic banking we can distinguish two trends (significant from the point of view of further consideration): internet banking and mobile banking. Their distinguishing feature is the technology of the service bank user interface. It seems to be a wrong way to attempt distinguishing between these distribution channels by the type of device used. This is due to the fact that differences between the personal computer (usually related to Internet banking) and mobile phone (assigned to mobile banking) are blurring.

Internet banking is the realization of banking services using an interface that is made in Web technologies. So these are the most common Internet banking services currently available through web browsers. This access channel has undergone a similar path of evolution to other solutions. Initially, only for information services, and then expand its functionality with basic active operations. And now it offers most of the services available in the physical facilities of banks. The main limitation appears to be the lack of widely available electronic signature mechanism. 
Mobile banking use applications created in mobile technologies. Their user interfaces are typically dedicated to devices of relatively small size (a palm size). The range of services offered in this channel is still growing and becomes a direct competitor to Internet channels.

\section{Evolution factors}

Looking for the assessment of the future of banking services, we must consider factors contributing to their past development. It can be expected that changes are the result of many processes, often influencing each other. It is also the thesis I can formulate. The evolution of banking services and distribution channels is the result of social, organizational and technological factors. These impacts overlap and create pressure to change the practice and scope of banking activities.

As social factors I would mention:

- Enrichment of the population, resulting in an increased interest in financial services. In response, banks extend their offer and develop the branch network

- Increase customer awareness, resulting from an increase in the level of education and experience in dealing with banks. For banks, this means greater competition in the market, because clients less trust in an opinion of the bank employee and more often compare various solutions. It also allows to offer more advanced services.

- The need to have analytical information, resulting in the emergence of services such as credit simulations, tools such as Personal Financial Manager (PFM), trend analysis of capital markets.

- The need for communication. One symptom of this is the fact that the cell phone is a modern device that we very often have close to us. Furthermore, a large part of the population is constantly on-line. Banks have a possibility to keep in touch with customers.

Organizational factors are:

- The end of the gold specie standard as a monetary system.

- Popularization of bills of exchange and promissory notes usage, what influence on the development of services related to bank money.

- A tendency to minimize cash transactions, giving an impact on offering a range of banking products and services. An example would be the popularization of plastic cards in the $60 \mathrm{~s}$ of the twentieth century.

- The development of cooperation between institutional entities. It resulted in agreements in the local and global scale (e.g. SWIFT organization) and achieving standardization of processes. Examples are SWIFT standards for the exchange of data between financial institutions, SEPA for payment exchanges in the Euro zone or EMV for smart cards. 
- Changes in legal systems. It can take a form of new regulations (like new prudential regulations) but also deregulation. Regardless of the direction of change, fundamentally affect the ability to offer certain services by financial institutions.

The last group of factors is associated with the technology development. As the most important we can identify:

- Technologies of communication for a long distance (telegraph), which resulted in the acceleration of settlement of transactions in relation to mail with a paper document.

- Electronics and increased functionality of electronic devices simultaneously with their miniaturization. This created a possibility to offer new distribution channels (electronic banking).

- Computer technologies, as a special kind of electronic revolution. The continuous increase in computer performance influences on banking information systems and thus allows providing more complex services. Further progress in this area leads to popularization of such concepts as BigData (possibility of data mining in large data sets) or in-memory processing.

- Internet. As a new communication media it allowed to offer a new distribution channel - internet banking. It also gave an opportunity to apply a new business model - a virtual bank and a virtual branch in the traditional bank. Internet accelerated an information exchange. In extreme cases leading to exchange data in real time (popular examples are: payment transactions or invoices exchange). The ability to maintain a continuous stable and secure Internet connection technology has allowed the development of cloud computing, which also can lead to a new bank business model.

- Biometric technologies. Currently used primarily in client authentication. However, we can assume that wider use is still to come.

- Mobile technologies allow keeping in constant communication with the bank regardless of where the customer is. That feature has opened a new distribution channel - mobile banking.

- Geolocation, partly related to mobile technologies. Allows to have an access to geographical location of the customer and in that way to customize services stronger.

- Short-range wireless communication technologies (such as RFID, Bluetooth, NFC). Although known for a long time, recently they are also used in banking. Contactless payments are an examples of such application. Another example can be a beacon, a small device becoming popular in recent years. In banking it can be used, among other things, for better offer personalization [8]. 


\section{Changes in bank environment}

The main change in the business environment is a strong increase of competitiveness. Primarily, it refers to the relationship between domestic banks and global banks entering a new market. Furthermore there are new players. These include other non-bank financial institutions such as credit unions, social lending portals, but also those in other sectors of the economy - insurance, , telecommunications, media and IT companies.

Particularly two phenomena are noteworthy. The first is a global technology corporations, like: Google, Amazon, Apple, Facebook, Alibaba. These Large Digital Players enter new service markets, previously controlled by banks. The second phenomenon are small business - technological startups. Both groups function as so called Big Bang Disruptors [9],[11]. They are characterized by: high efficiency, low cost, effective cooperation in creating content, innovative content, enhanced personalization, advanced technology solutions. The life cycle of products offered by these companies is very dynamic. It is characterized by rapid growth in popularity at the beginning, a short time of being on top and a sudden rapid decline of interest. A single occurrence of such company is not relevant for the environment, but in the global scale there are many of them. Their life cycles overlap. This allows customers to move from one innovation (currently on top) to the another (now at the beginning of rapid growth). As a result, it is a need for continuously monitoring and responding by large entities (including banks) to the market situation.

An example of innovation affecting the banking market can be the immediate payment market of in Poland. For a long time execution of credit transfer was the domain of banks and was managed by the National Clearing House (KIR SA). Most often, transfers were settled within a few hours. At some point in time, some companies (e.g. Przelewy24, PayU) entered that market as intermediary party. Based on the mechanism of real-time internal transfers existing in core banking system, they built a system allowing for immediate credit transfers between banks. The next step was done by Blue Media company, who proposed the new system (BlueCash) with implementation of immediate transfers, what became a direct competition to National Clearing House services. To prevent losing potential income, banks had to respond to the demand. Hence, KIR SA launched an Express ELIXIR system in 2012.

Another example may be a virtual currency (e.g. Bitcoin), by which the banking sector is motivated to develop their own systems of electronic money.

Growing competition on the market, transforms it into a customer market. The level of customer satisfaction becomes more important for banks in a short period of time than profit maximization. Customers' needs must be 
identified and answered quickly. A method of achieving this goal is a technological development.

IT development as a bank priority requires changes in bank organization. The role and responsibility of IT departments increases. Generally, a structure of employment is changing in favor of technology professionals. Bank employees responsible for contacts with customers also need to have a deeper IT knowledge.

Next aspect is a software engineering methodology. Habitually, banks applies traditional cascading methodologies, what results in production cycles lasting for a few months. It is too long in a new dynamic bank environment. The aim is to shorten these cycles, for example using agile methodologies.

Next observable trend is the blurring of boundaries between bank and other entities offer. On the one hand, banks are entering new markets like insurance, telecommunications or media. From the other side, representatives of other sectors extend their offer of banking products and services. Due to legal restrictions, it requires a cooperation between a bank and other companies or purchasing a bank and its banking license. There are few such examples on the Polish market. Among them alliances concluded between telecom TMobile and Alior Sync bank, between telecom Orange and mBank. Another example is the Plus Bank that is a part of the capital group consisting a telecom (Polkomtel) and a media group (Cyfrowy Polsat SA). One of the effect of such cooperation is product bundling, what means offering several products of different kinds in one combined offer. This strategy is advertised as win-win game for the bank and its associates. Cooperated parties can share their best practices, distribution networks and technologies.

One of the most famous attempts to gather all these trends in the banking sector is the concept of Bank 3.0 defined by Brett King [10]. He says about banks after the recent global financial crisis, operating in a dynamic competitive environment. As a consequence banks have to evolve organizational and technological. King asks the question 'Why banking is no longer somewhere you go but something you do' and in that way he defines a new perception of banks by customers and the future role of banks. In this concept, in order to survive, banks should:

- Reduce the role of traditional branches and concentrate on customer support. Instead of that virtual branches should be popularize.

- Cooperate with social media.

- Make banking systems more flexible and adapt them to work in a cloud environment.

- Bank staff need to be more familiar with high-tech solutions.

Another interesting concept is promoted by Accenture. It proposes a new bank business model called The Everyday Bank $[9,12]$. According to this vision, banks have to broaden their range of non-financial services and introduce new digital distribution channels. The Everyday Bank has a central posi- 
tion in customer everyday life and will act as an intermediary between the client and other entities in the digital economy. In addition, customer services should be carried out within a so-called 'omnichannel' environment. It makes an assumption that the choice of distribution channel should not affect the perception of the process by the customer. Moreover, customer service process can be performed in different channels alternately.

\section{Technology trends}

As previously mentioned, technological innovations overlap. Before one reaches its peak of popularity, another one starts to gain market share rapidly. To stay in business, banks have to adapt and respond quickly to new innovations.

Key technologies that can have the greatest impact on evolution of banking services and distribution channels are:

- Mobile technologies. They form the fastest growing distribution channel and allow to offer new services - e.g. mobile payments.

- Electronic money.

- Biometrics. It is a group of methods widely used for authentication, to confirm the identity (equivalent of Personal Identification Number) or identification (equivalent of login).

- Cloud computing.

- Big Data - analyzing huge data repositories to discover new useful knowledge. It is a technology that allows better understanding of the customer behavior, anticipating customer's needs and offering better suited methods of communication.

- Behavioral Systems - examining customer behavior, including location data, transaction characteristics.

- Social media - can be used as a new channel of communication with customers but also as a new distribution channel. As an example a social payment can be mentioned. In this solution a social media portal become a place where we can send or receive a payment.

- Geomarketing - it the use of geographical parameters to carry out marketing campaigns. In banking practice it is used to decide on the location of the banking infrastructure (like bank branches, terminals, POS), to adjust marketing efforts to target groups residing in the area.

The use of new technologies results in a number of new services offered by banks. Below there are two examples of services that enrich the standard functionality of banking services. They are not critical from customers point of view, but they increase attractiveness of the offer.

The first example is a service named mRabaty offered by mBank. It uses a mechanism of geolocation of customer phone cell so is dedicated to be used 
in the mobile channel. In that solution, system identifies discounts available for the customer, classifies them on the basis of some preferences and current customer location. Finally all identified proposals are marked on the map displayed on the phone screen.

Another example is a tool for analyzing and managing of customer's own financial data. It can use data mining methods, for example to classify payments according to transaction features and assign them to a specific expense category and proper line item in the personal budget. A general name for such solution is Personal Financial Manager (abbreviated to PFM). Many banks offer such a functionality in their transactional systems. Moreover, there are also many non-banking sites on the market that specialize in this area (e.g. national: kontomierz.pl, ifin24.pl, budzetdomowy.pl, eportfel.com; global: yodlee.com). There are significant limitations in the development of PFM tools. First of all, it is difficult to extract data about the history of transactions from various banking systems and collect then in one system. There is no universally recognized standard for exchanging such data. Usually PFMs use a not very stable and secure technique called 'screen scraping' or inefficient manual input of data. Furthermore, a problem of recording cash transactions remains unresolved. Regardless of existing problems, this type of tool can be treated as a response to the need for analytical data by advanced online users.

\section{Conclusions}

The surroundings or conditions in which banks operate is constantly changing. From the bank point of view, it determines the need for continuous monitoring and responding customer expectations. This also creates a business opportunity for others financial market players. It is one of the areas in which Polish banks and the whole economy may prove to be innovative.

For bank customers it results in constant change of banks' distribution channels and services. In banks' assumption these changes should be better suited to customer needs. Is that realize indeed? It is a subjective matter. It is not hard to find opinions that financial offers have become unnecessarily complicated and new services, except attractive appearance, have little added value.

\section{References}

1. In three years smartphones became a main distribution channel for banking services, Deloitte, PRNews.pl, 2013-06-17 (in Polish).

2. Polish Banking Law, The Act of 29 August 1997 r., (OJ of 1997. No. 140, item. 939) (in Polish). 
3. Paterson R., Compendium of Banking Terms in Polish \& English, Fundacja Rozwoju Rachunkowości w Polsce, Warszawa 2002, p.168.

4. New mBank for 100 million PLN, www.biznes.newseria.pl, 2012-03-29 (in Polish).

5. A new logo and transactional system of mBank. 100 million PLN on rebranding, www.wirtualnemedia.pl, 2013-06-05 (in Polish).

6. New mBank is a most groundbreaking innovation in the world, www.mbank.pl, 2013-10-12 (in Polish).

7. Samcik M., Alior Sync ready to go live! But is this really the bank hit, we've been waiting for?, samcik.blox.pl, 2012-06-13 (in Polish).

8. What Beacons could do for banks and retailers?, www.monitise.com, 2014-0520.

9. Mazurek K., The Everyday Bank, Accenture 2014, www.alebank.pl (in Polish).

10. King Y. B., Bank 3.0: Why Banking Is No Longer Somewhere You Go But Something You Do, Wiley 2012.

11. Downes L., Nunes P., Big-Bang Disruption, Harvard Business Review, March 2013, hbr.org (2015-11-15).

12. The Everyday Bank, A New Vision for the Digita Age, Accenture 2015, www.accenture.com (2015-11-15). 